\title{
Hrvatski vojnici i civili u vrtlogu Velikoga rata (1914. - 1918.)
}

Stogodišnjica Velikoga rata, danas poznatijeg pod nazivom Prvi svjetski rat, obilježena je posebnim istraživanjima, skupovima i izložbama te brojnim znanstvenim i popularnim izdanjima u mnogim zemljama. O značenju Prvoga svjetskog rata, promjenama koje je donio i njegovim posljedicama ispisane su brojne stranice. O dojmu koji je ostavio na suvremenike mnogo govori i njegov prvotni naziv, Veliki rat te je stoga upravo taj naziv ovdje korišten u naslovu bloka. Ipak, mnogo je toga ostalo neistraženo. U odnosu na historiografije drugih europskih zemalja, u hrvatskoj je historiografiji do početka obilježavanja stogodišnjice bilo malo radova s tematikom vezanom uz Prvi svjetski rat. Od 2014. do danas vidljivi su znatni pomaci. Tematskim blokom koji počinjemo u ovom, a nastavit ćemo u sljedećem broju Časopisa za suvremenu povijest, pridružujemo se obilježavanju stogodišnjice, ali i poticanju istraživanja različitih aspekata ratne stvarnosti.

Tematski blok o hrvatskim vojnicima i civilima u turbulentnim vremenima Velikoga rata ima cilj pomoći osvjetljavanju slabije istraženih tema, a nadamo se i otvaranju novih. Polazeći od činjenice da su prilikom prijašnjih obljetnica događaja vezanih uz Prvi svjetski rat uglavnom bile zastupljene teme političke povijesti, prvenstveno one vezane uz početak i kraj rata, pri pokretanju ovoga bloka misao vodilja bila je kako potaknuti temeljitije istraživanje zbivanja tijekom središnjih ratnih godina, 1915., 1916. i 1917., a u tematskom smislu istraživanje svakodnevnoga života u pozadini i na ratištima, istraživanje vojne povijesti, financijske strane rata, pravne povijesti, povijesti humanitarnih nastojanja, lokalnih zbivanja te brojnih drugih tema. Nadam se da s krajem obilježavanja stogodišnjice Prvoga svjetskog rata neće nestati interes za to razdoblje, a nadam se i da ćemo do 2021. realizirati i tematski broj časopisa posvećen temama uspostave mira, promjenama i posljedicama koje je ostavio te memoriji Prvoga svjetskog rata.

U ovom broju objavljujemo dva priloga posvećena temama iz Prvoga svjetskog rata: prvi dio opsežnoga rada pukovnika Nikole Tominca o Hrvatima u Brusilovljevoj ofenzivi i rad doc. dr. sc. Mirele Krešić o pravnom institutu proglašenja nestalih vojnika umrlima. Tematski blok nastavit ćemo u sljedećem broju. 
Ovaj tematski blok ujedno smo iskoristili kao ogledni primjer za uvođenje određenih promjena u načinu pisanja referenci kojima je cilj rasteretiti radove dvostrukoga pisanja potpunih podataka, i u bilješkama i u popisu izvora i literature. Detaljnije upute o promjenama nalaze se na kraju broja.

Na kraju valja istaknuti da tematski blok o Prvom svjetskom ratu koji će Časopis za suvremenu povijest objaviti u nastavcima ne bi bilo moguće realizirati bez velikoga entuzijazma i stručne potpore kolegice Vijolete Herman Kaurić te rada većega broja vrijednih članova Udruge 1914. - 1918., volonterske udruge profesionalaca i entuzijasta okupljenih na dokumentiranju, istraživanju i komemoriranju pojedinih sastavnica Prvoga svjetskog rata (https://www. facebook.com/udruga.1914.1918/).

Zdravka Jelaska Marijan 